\title{
ANALYZING REJECTION OF CORPSE INFECTED BY COVID 19 IN THE PERSPECTIVE OF MORAL PANIC AND FIQH SOSIAL THEORIES
}

\author{
Muhammad Labib \\ Sunan Kalijaga Islamic State University \\ Email: muhammad.labib6666@gmail.com
}

\begin{abstract}
This research discusses an interdisciplinary study of Covid 19 excesses that is currently affecting the world, including Indonesia. There were cases of stigma and rejection of corpse infected by Covid 19 that occurred in Banyumas, Lampung, Gowa, South Sulawesi, and Semarang. The theory used as an analytical tool is Stanley Cohen's theory of moral panic to understand the background of community actions, and subsequently uses the social fiqh theory to reinforce the building of an argument for scientific response to the case. The method used in this research is library research by making effective data obtained from reliable online news, journals, and books that can be accounted for. The results of this study are: (1) The perspective of Stanley Cohen's moral panic theory explained that the case of the rejection of the corpse of Covid 19 was triggered by excessive public panic and anxiety until "social / health panic" is closely related to the term "moral panic" in Cohen's theory. This gives the consequence of giving stigma and discrimination of Covid 19. (2) The perspective of social Fiqh with the application model of Madzhab Qauli, the act of refusing a corpse infected with Covid 19 is "a wrong way" in Islamic legal norms. This claim of Islamic law is considered to be in harmony with the maqashid syairah which is understood from Abdul Majid Najjar's thoughts about the maqasid hifdzu al karamah al insaniyyah.
\end{abstract}

Keywords: Rejection of Corpse; Covid 19; Moral Panic, Fiqh Sosial

\section{Introduction}

Corona virus desease (Covid-19) has been declared as a global pademic phenomenon by WHO Director General Tedros Adhanom Ghebreyess in a press conference on March 12, 2020 (CNBC, 2020). Increasing the number of cases, patients diagnosed positively and who have been declared dead. April 24, 2020, there were 2,725,957 Covid 19 cases scattered throughout the world. From these, as many as 191,061 people died and as many as 745,956 people were declared cured. Indonesia, which now ranks 35th in the world in this case, has 7,775 cases. As many as 647 people have died, and 960 people have recovered. (Worldometer, 2020).

Covid 19 (Corona Virus Desease 2019) is a virus that is related to(attacks) the respiratory infections with initial symptoms such as flu, ranging from 
dizziness, fever, cough, runny nose, sneezing, and others. The virus, which was originally discovered in Wuhan, China, was allegedly transmitted to humans through bat intermediaries. Previously, Before this virusit becames a pandemic after, actually 2 types of viruses have been found, namely, known as SARS-CoV and MERS-CoV which were also initially transmitted between animals and then to humans (Whang Zou, 2020).

The rapid spread of the Covid 19 outbreak in Indonesia also raises various branches of problems. Ranging from economic problems, worship practices, education, and the problem of social conflicts that heat up. Included as a social conflict that occurred in the community recently is the stigma and rejection of the corpses who died due to being hit by the Covid 19 outbreak in public burial ground in a number of areas. This case occurred in the areas of Banyumas, Lampung, and Gowa in South Sulawesi, and the last to take legal action was a case that befell the bodies of nurses in Suwakul village, West Ungaran District, Semarang Regency (Kompas, 2020). This action, allegedly occurred due to the influence of the panic condition of the community infected with the virus because the location of the cemetery is close to the set thlement (Kompas, 2020).

In general, the actual norms of Islamic law (read: fiqh) collectively oblige (fardhu kifayah) for Muslims to care for every corpse with a various treatments such as bathing the corpse, shrouding, praying, and burying. This obligation applies to non-corpses who died on the battlefield because they fought for jihad fi sabilillah against the enemies of Islam. It is called the body of a "syahid", and the obligation to treat it is only to bury it.

Meanwhile, bathing, shrouding, and praying is not compulsory, because in Islamic legal norms the body and clothes worn by the corpse while on the battlefield will be witnesses in the last days of the sacrifices that have been made. There is also the term corpse "syahid akhira" which is privileged by Islamic legal norms, that is, Muslims who die from drowning, are killed in wrongdoing, in the process of seeking knowledge, stomach ache, and plague. However, in contrast to the first category of "syahid", the body of "syahid akhira" must still be treated the same as the bodies of Muslims in general (Al-Anshari, 2010), (Muslim, 2008). 
In this case, there is a gap between Islamic legal norms and the reality of community action. Bodies of victims infected by Covid 19 who should still be obliged to be handled in accordance with the bodies of Muslims in general with a standard burial protocol from medical policy, in fact there were rejected to be buried at the intended burial site. The facts outlined above which have been backed up by various mass media in such a way, have a significant impact to the community psychological condition. Therefore, the rejection of Covid 19's body has become a social phenomenon that needs to get an argumentative scientific response in order to prevent similar incidents in the future.

Based on the background, the author is encouraged to discuss the rejection of the corpse infected by Covid 19 through an interdisciplinary study of the approach of Stanley Cohen's moral panic theory and fiqh sosial Sahal Mahfudh. The theory of moral panic in turn will serve to map the background, sit the stigma and rejection of the bodies of Covid 19. Meanwhile, fiqh sosial theory, presented as an approach to analyze and respond to the rejection of the burial of the body in accordance to the values and norms of Islamic law.

\section{Moral Panic Theory of Stanley Cohen}

The theory of moral panic was originally introduced by Stanley Cohen, a 1986 Nobel Prize-winning biochemist from the United States who just died on February 5, 2020. It is actually the result of Cohen's research to get his $\mathrm{Ph}$. $\mathrm{D}$ in 1967 - 1969 which was published under the title "Folk Devils and Moral Panics" which received a lot of responses, criticisms, and comments from the experts. In his research, Cohen focused on the phenomenon of the Mods community (youth communities fashion style, carrying scooters, and involved in fights with motorcycle gangs) and Rockers in the 60s of UK (Cohen, 2002).

Both of these communities are considered as sub-cultures that disturb society, both from the style of clothing, behavior, and habits that are considered to deviate from the prevailing social values and norms. Through the role of writers / media the two communities are described in such a way that they begin to get a negative response and finally a set of social control measures are taken. In Cohen's terms, the phenomenon of the Mods and Rockers community is referred to the "folk devil" (enemy of society) which in the Middle Ages was heavily pinned on the 
wizard community. Then, the condition of society and the role of media in a disproportionate reaction to actions deemed deviant from the prevailing values, social and cultural norms, as a result of exaggerated feelings of panic or threatened are called "moral panics" (Noortyani, 2013). In summary, it can be mapped that there are three pillars of analysis in the theory of moral panic, ; (1) the condition of "moral panics", (2) the stigma of "folk devil", and (3) the role of writers / mass media.

To identify the condition of "moral panic", Cohen explained 5 stages, ; (1) a person, something, or a group, defined as a threat to social norms or community interests, (2) The media then described this threat with simple symbols or forms and easily recognizable, (3) The depiction of this symbol raises public unrest, (4) The response arises from the authorities and policy makers, and (5) The moral panic that arises over this problem then creates social change in society. In harmony with the above stages, Cohen also mapped 5 attributes can be used to be the indicators in analyzing moral panic; (1) "concern", represent an increased level of anxiety about perceived social threats, (2) "hostility," (3) "consensus," It happens when people agree that certain threats are "real-serious-and caused by group members' mistakes and their behavior ", (4) "disproportionality ", that is, when the intensity of public awareness exceeds the actual threat of social problems, (5) "volatility", conditions arising from panic eruption and disappear suddenly and without warning. (Cohen, 2002).

While "Folk Devil" (enemy of the people) is a term or stigma used to describe the perpetrator as an enemy of the community because it is seen as endangering the values and norms of the community exemplified such as Mods and Rockers. (Cohen, 2002). Then, the media as "the primary source" for public knowledge, in the theory of moral panic has a fairly vital role in bringing about the perception, assumptions and stigma of "folk devil". Some basic assumptions about the role of media,; (1) setting the agenda - the media in the description of the news is able to lead discourse against the public to bring up the selection of the person who deserves stigma or is considered to threaten the values and norms of the community, (2) transmitting the images - the media transmits the claims conveyed by the figures to sharpen the rhetoric moral panic, (3) breaking the silence, making 
the claim - the news is able to create a claim with the title and news content that (in the current language) click bait (Cohen, 2002).

At first glance, this theory actually applies to the analysis of "deviants" or "social pathologists" or what are called parties that threaten norms and values in the social system. However, this theory can actually be developed to understand the problem of the Covid 19 corpse which is considered as a "threat" to the community in terms of their health will be analyzed in the discussion. The use of the 3 tools of the analysis, namely the condition of "moral panic", claims or stigma of "folk devil", and the role of "the media", will be very relevant to be used in analyzing the background of community rejection.

\section{Fiqh Sosial Theory of Sahal Mahfudh Al-Hajaini.}

This theory "Fiqh Sosial" based on Sahal Mahfudh The supreme leader of the largest Islamic organization in Indonesia Nahdlatul Ulama since 1999 - 2010, is a thought and concrete movement which then crystallizes in the hands of his students who are members of the study center in Pati, namely Pusat Studi Pesantren dan Fiqh Sosial (Pusat Fisi) which develop the intellectual heritage of Sahal Mahfudh into a systematic idea and neatly booked so it is suitable to be used as a scientific methodology.

Fiqh Sosial has two relevant analytical models can be used as an approach in responding the social problems. The two are Madzhab Qauli and Madzhab Manhaji which are used sequentially. That is, to answer social problems, the first model (madzhab qauli) is used first, if it is deemed impossible, the second model (Madzhab manhaji) can be used to complete it. (Umdah and Tutik, 2016). The application of madzhab qauli in analyzing a social problem is to contextualize the "kitab kuning" (a classic literature in Islamic law) or through the examples development of qawaid ushul fiqh and qawaid fiqh. Meanwhile, the application of Madhhab Manhaji is by developing masalikul illah -a set of methods used to trace and select the most relevant legal reasons as a basis for establishing Islamic law (Zuhaili, 2015)- so that Islamic legal products are in accordance with the maslahah ammah. (Sahal Mahfudh, 2007).

The Research Center for Pesantren and Fiqh Sosial (PUSAT FISI) IPMAFA as a catalyst for the thought of Sahal Mahfudh, added the use of istihsan, and allowed 
openness to all madzhab of fiqh (islamic law), also allowed openness to all inventions from all science especially for social sciences, natural science and technology. Unfortunately, in analyzing the case of rejection of the corpse infected with Covid 19, the author only used the model of madzhab qauli. That is, because the case is assumed as a little complexity and does not require to the use of the model of madzhab manhaji.

Then, as a foundation of the provisions of a thought, fiqh sosial also presents maqasid syaria as a very important entity. Maqasid shyaria has a function to control over the demands of openness thought iacross disciplines, while at the same time its function is to avoid interests and egocentrism (Umdah and Tutik, 2016). Included as a well-known figure referred to the pioneer of systematic maqashid sharia, As-Syatibi in his book Al-Muwafaqat. He introduced 3 priority concepts of maqashid sharia, ; (1) Daruriyyat (primary), (2) Hajjiyat (secondary), and (3) Tahsiniyyat (tertiary) (As-Syatibi, 1997).

After As-Syatibi, al-kulliyat al-khomsah was initiated by Al-Ghazali as a taxonomy of maqasid syaria. It means that all claims of Islamic law must be in harmony with 5 things in the form of hifdzu ad-in (faith), hifdzu an-nafs (life), hifdzu al-aql (education-intellect), hifdzu an-nasl (posterity), hifdzu al maal (wealth) (Al-Ghazali, 1983). In the contemporary era, there are some contextual and relevant ulama' thoughts to be used as an approach in responding the problems. Among of them, the analysis tools had choosen in this study were the thoughts of Abdul Majid Najjar. He developed the concept of maqashid Hifdzu AlKaramah Al-Insaniyyah (preserving human glory) as a continuation of hifdzul nafs (protecting live). It is based on the verses of Al-Isra ': 70:

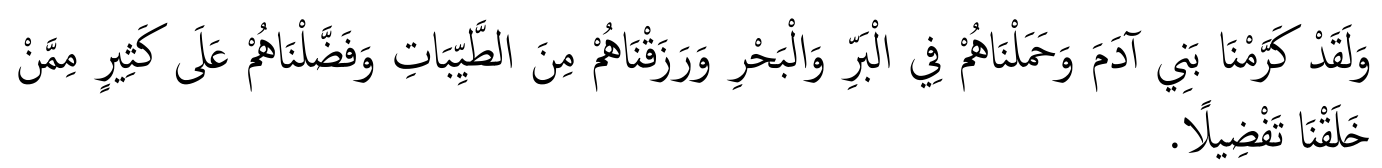

Meaning: "And we have truly glorified the offspring of Adam. We transport them on land and sea, We give them good fortune and We prioritize them with perfect virtue for most of the creatures that we have created."

The human glory means to make it noble as it is created (without any additional such as wealth and position) and it must not be underestimated by others. Among the implementations of human glorification is to believe that 
humans have features and things very valuable, there is the nature of majesty, nobleness of character, and believe that other beings are subjected (taskhir) to be led by humans. This basic principle is one of the objectives of maqasid syaria. It has enormous implications for Islamic legal products in responding social problems that must keep humanity in mind. All words, deeds which threaten the glory and majesty of humanity are respected by Islamic law is forbidden (AM. Najjar, $t$ th).

\section{Research Methods}

The method used in this study is library research. It can be interpreted as a series of activities related to the method of collecting data, reading and recording and processing research material. There are four main characteristics in library research, namely: First, the author deals with text (or numeric data, not with direct knowledge from the field. Second, the library data is "ready to use" meaning that the researcher does not go directly to the field. Third, library data are generally secondary sources, in the sense that researchers obtain material or data from the second hand and not the original data from the first data in the field. Fourth, library data conditions are not limited by space and time. (Mestika, 2003). Based on the selection of this research method, the authors used secondary data sourced from journals, books, online news sources that are up to date and other relevant and credible scientific writing outputs.

\section{Result And Discussion}

\section{Sociological Background in the Case Of Rejection Corpse Infected By Covid}

The Cases of rejection of corpse infected by Covid 19 have occured in several regions in Indonesia, Including the shocking occurred in the Banyumas region on March 31, 2020. Precisely in four districts, namely Purwokerto Timur, Purwokerto Selatan, Patikraja and Wangon. In fact, the body that had been buried with medical standards that had been carried out had to be dismantled. It is happen in the land owned by the regency in Tumiyang Village, Pekuncen District, Banyumas Regency, Finally, the Banyumas Regent Ir. Achmad Husein intervened to reduce the heat situation and prepare alternative land to bury the body. Not only the Regent, Central Java Governor Ganjar Pranowo also appealed to the people of Central Java, especially Banyumas not to reject the corpse infected by Covid 19 on humanitarian grounds. The motive in this case is that the community is worried 
about contracting a virus carried by a body buried near the settlement (Kompas, 2020).

A similar case also occurred in Bandar Lampung. Reihana, Head of the Covid 19 Task Force in Bandar Lampung in Monday, March 30, 2020, said that there had been two rejections. First, in Batu Putuk, Teluk Betung Barat, TPU Bukit Kemiling Permai, Kemiling District. Second, after being rejected at the location, the body was moved to the Bukit Kemiling Permai TPU which resulted in a rejection by the residents. Finally, officers buried the body in the land owned by the Lampung Provincial Government in Kota Baru by excavating the land as deep as 8 meters on the grounds of following WHO standards (Kompas, 2020).

Meanwhile, another incident also occurred in Gowa, South Sulawesi, precisely on the land owned by the Provincial Government,TPU Macanda, Teratai Indah Macanda's road, Romang Polong Village, Somba Opu District, Gowa Regency, South Sulawesi, on Thursday, April 4, 2020. In the case dozens of residents living around the TPU held demonstrations, roadblocks with trees and burning tires. The action began with provocation from 5 persons who had been arrested by the police (Liputan 6, 2020).

Then, the incident of rejection of the corpse infected by Covid 19 also occurred at Siwarak TPU, Suwakul Village, West Ungaran District, Semarang Regency on April 9, 2020. The victim was a nurse at the Kariadi hospital Semarang, who died due to positive contracting of Covid 19. It occurred due to provocation from 3 suspects who had been secured by the police. According to Semarang District Prosecutor General Criminal Rahmat Wibisono, the case files are complete and the three provocateurs suspects are ready to be brought to judicature (CNN Indonesia, 2020). The Community leader RT 06 of Suwakul Village, Mr. Purbo who is one of the suspected provocateurs, through a video uploaded on the Instagram account @ndorobeii apologized for the rejection. He clarified that his duty was only trying to convey the aspirations of the people who refused the funeral of the victim. Even in one video upload residents during the incident of rejection, stated that the victim's body was burned or cremated in order to prevent transmission of the virus (Suara Jateng, 2020). 
The actions to reject the burial of the corpse is a concrete situation of the psychological condition of some Indonesian people who feel anxiety and panic with the phenomenon of the Covid 19. In this case, the rejection of these people basically does not occur spontaneously, but there is a set of historical and psychological processes behind.

This condition of society is similar to what is described in Stanley Cohen's "moral panics" theory. Cohen's analysis explicitly stated that the community's concern for the existence of actors, both individuals and groups, is considered to threaten the prevailing norms and values. In these cases, community concerns are caused by the Covid 19 virus itself which is attached to the body and is considered to be contagious even though it has been buried in the ground, which is considered to threaten the health of the people living near the burial site. For the purpose of contextualization and to emphasize the relevance between the term "moral panic" and the reality of people's concerns or panic towards potential health threats, it would be more appropriate if the term was termed "social panic" or "health panic" in this analysis.

This social/health panic condition was also triggered by a large number of news and character analyzes that were disseminated by the mass media. This is consistent with Cohen's analysis that the media has a significant role in framing or making claims, thus provoking the public towards a particular agenda. Basically, even though the media is neutral in reporting, or even has the initial aim of inviting the public to be aware to the Covid 19 pandemic, the community indirectly has different interpretations and perceptions. Against a background of psychic conditions that are worried or panicked, the actions of Banyumas, Lampung, Gowa, and Semarang people actually lead to the opposite action, in the theory of moral panic is called "disproportionate action". By the news shows every day, supported by the sophistication of smartphones, whatsapp applications, Instagram, Facebook, Twitter and other social media that often spread hoax content, the public is increasingly panicked and raises a "consensus" to take action.

The corpse infected by Covid 19, which has been sprawled without a life, has been the victim of 2 tragedies. First, because of a virus he died, and second, he received stigma and discrimination because of carrying the virus. In Cohen's 
theory of mass panic theory, the body could be categorized as a "folk devil" stigma or what was considered as an "enemy of the people". Actually what is opposed by the community is the Covid 19 virus. However, because the virus is in the body, then the perception of hostility towards the body becomes inevitable.

\section{Rejection of Corpse Infected By Covid 19 in Perspective of Fiqh Sosial}

As the application of madzhab qauli in analyzing this case, the author traces some popular ulama- faqih thought from the "kitab kuning" (classic literature in islamic law) which is credible in the academic writing tradition "mu'tabar". First, Imam Nawawi who has authority in the syafi'iyyah madzhab explains that handling of the Muslim corpse by bathing, shrouding, praying, and burying it in Islamic legal norms is fardhu kifayah (collective obligation) or responsibility which is imposed on all Muslims, but can be done if completed by at least one person. This law is a consensus "Ijma" which has been agreed by all ulama and Islamic law experts. This conclusion is as explained in the book Imam Nawawi "Al-Majmu" Syarh AlMuhazzab "; (An-Nawawi, t th). This conclusion is as explained in the book Imam Nawawi "Al-Majmu" Syarh Al-Muhazzab ":

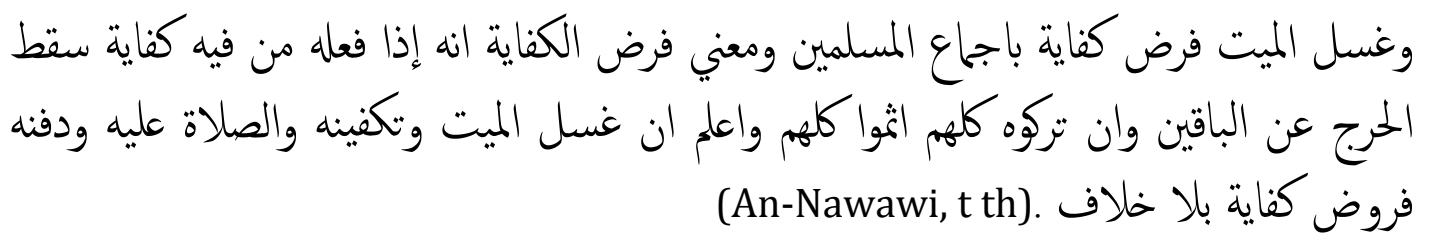

Meanwhile, for corpses from other religion, Muslims who are still living, in the Shafi'iyyah madzhab are just obliged (fardlu kifayah) to shroud and bury them. As for bathing, it is not obligated, and praying is forbidden (Al-Anshari, 2010). This is as stated by Abu Yahya Zakariya Al-Anshari;

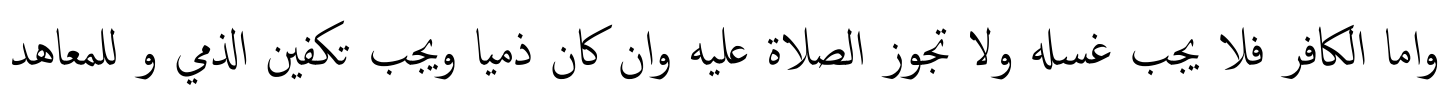

(Al-Anshari, 2010). ودفنها

Second, the opinion of Abu Bakr bin Muhammad Syatho Ad-Dimyati in his book Hasyiyah I'anah At-Tholibin, which explains that in Islamic law the term known remains of Muslims who died in a state of "syahid akhira", the bodies of Muslims who died due to causes certain people get rewards like Muslims who die because of the war against the enemies of Islam. These causes, such as; drowning, 
crushed by building, missing and lost, killed, stomach ache, and those who died during the epidemic (tha'un), although for other reasons on the condition of patience and conscience (in prevention or treatment), or died after the epidemic was over, while he was also affected by the plague. Unlike the Muslim who died in a battle, syahid akhira in the Hereafter is the same as a normal Muslim corpse in the context of handling. It means, the corpse is still must to be bathed, shrouded, prayed, and buried (Ad-Dimmyati, $\mathrm{t}$ th).

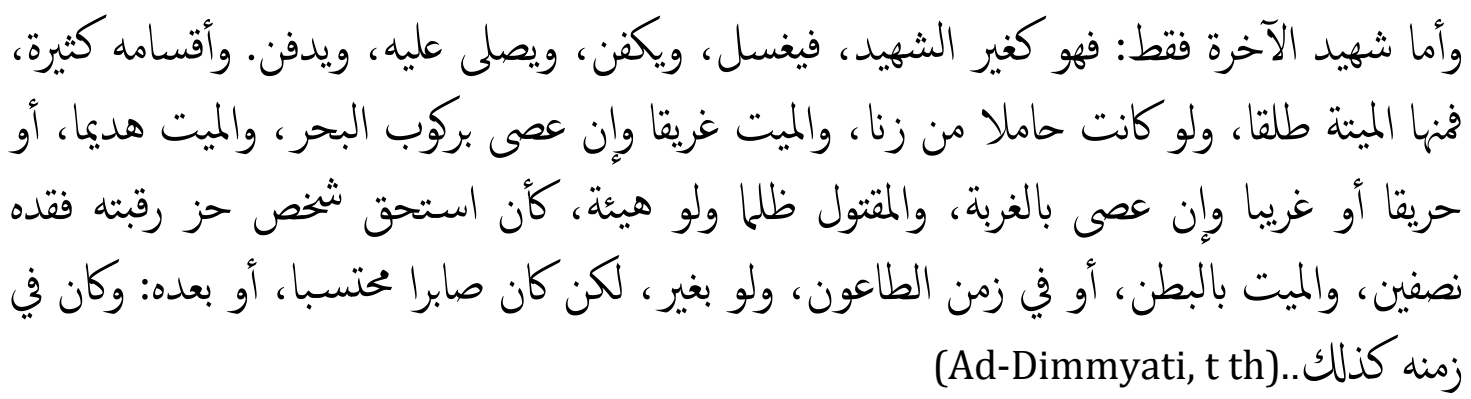

Third, as the previous opinion, Shaykh Nawawi Al-Bantani Al-Jawi explained that the bodies that died during the pandemic were categorized as "syahid akhira" and had the same reward as the bodies died in the battlefield contained in the Qs . Ali Imran: 169, and must be handled like a corpse that is not martyred, and must be handled like a corpse that is not martyred (Al-Bantani, $t$ th).

The bodies of Muslims who died infected by Covid 19, which had been designated as a pandemic, were categorized as corpses who were "syahid akhira" who still had to be handled like Muslim corpses in general. Starting from bathing, shrouding, praying, and burying. As for corpse from other religion, it remains obligatory to be shrouded and buried. So, all actions that disturb the process of handling the bodies, including this case are not justified in the norms of Islamic law, and it was the wrong way. For Muslims who are close to the corpse, in fact are responsible in accordance with Islamic legal norms to contribute to handle of the corpse. The obligation is fardhu kifayah or a collective obligation that can be done if at least one person handles of the body.

In addition for applying or contextualize "kitab kuning" which is containing opinions from ulama, in the madzhab qauli also applied the development of examples of qawaid ushuliyyah or fiqhiyyah (set of rules in the ushul fiqh theory and fiqh). One of the rules of fiqh (qawaid fiqh) that can be used as a tool to 
respond to this case is; "Not considered (as a consideration of Islamic law) allegation that proven wrong."

This fiqh rule becomes a guideline in Islamic law that the alleged "dzan" which is wrong cannot be used as a basis for legitimating a person's actions. For example a case of someone who suspects that when the prayer time has entered, he then performs the prayer, after the new prayer is proven that the allegation is wrong (by looking at the clock for example) then the prayer becomes invalid, and must repeat "i'adah" (As-Suyuti, 1982).

The development by using this fiqh principle, can be used as a guide in Islamic legal norms in responding to cases of rejection of corpses infected with Covid 19. The application is in the context of decisions from each community in Banyumas, Lampung, Gowa Sulses, and Semarang to reject bodies with concerns or allegations. It is becauese of the corpse that died from being infected with the Covid 19 virus, it is still possible to transmit the virus. However, referring to the existing of medical statements, this community's allegation proved to be untrue.

According to the statement of the forensic expert at the National Police Headquarters, Kombes Pol. Dr. dr. Sumy Hastry P, SpF, explained that the Covid 19 virus will die along with its host, who died (in this case the body). However, there is still a possibility that the virus will come out with the fluid from the body. Therefore, the process of handling the bodies must be fast, carried out by the forensic team from the hospital with complete personal protective equipment (APD), all body holes covered with cotton, the bodies were sprayed with disinfectants, the bodies were tightly wrapped with plastic, and buried with grave excavation depths. 1,5 meters (Liputan 6, 2020).

Meanwhile, based on the data traced came from several available online media, the corpse infected with Covid 19 which was rejected by the community from 4 regions above, was proven to have been handle of according to medical protocols from the hospital, burial staff also from the hospital, delivered by ambulance, even cases that occur in Lampung are buried with a depth of up to 8 meters (Kompas, 2020). Based on medical fact, which proves that the public's suspicion of the virus from the body of Covid 19 is wrong, then the allegation cannot be used as a justification for the rejection. There also other rule of Islamic 
law (qawaid fiqh) which is relevant to analyzing this case;"A danger must not be eliminated by method / other forms of danger".

According to Ibn As-Subuki, as narrated by As-Suyuti argued that this is a branch of the fiqh rule that "all dangers must be eliminated". As for the rules above, it means that in Islamic legal norms it is not justified to/ it is a wrong way to use danger methods to eliminate another danger, it can be a case of general danger with specific danger, or the same danger status between two things. Examples of cases that are not allowed to force neighbors to build guardrail (where it function to avoid danger, while that force is also a separate danger), or are not allowed to eat food from friends who are both in an emergency to simply maintain survival (As-Suyuti, 1982).

The development of this rule in the case of the rejection of a corpse infected by Covid 19 is, clearly that it is a dangerous virus that can threaten a person's life. However, the preventive action by carrying out the act of rejection is also a separate danger and detrimental to various parties, especially victims and their families. Moreover, supported by medical statements about the death of virus along with the death of its host, as well as the implementation of a funeral process that still uses medical protocols. Based on this guideline, taking precautions to prevent the transmission of the Covid 19 virus by rejection is not justified and is not in accordance with medical facts and Islamic legal norms.

Maqasid syaria becomes an important entity to develop Islamic law trough Fiqh sosial theory, explicitly presented as the basis as well as the direction of the provisions of a law, in controlling the demands for openness thought in crossdisciplinary disciplines, while at the same time Its function isto avoid interests and egocentrism.

Referring to the results of the analysis above with the model of the madzhab qauli of fiqh sosial, the conclusions narrowed to the statement that the rejection of the corpse infected by Covid 19 in Banyumas, Lampung, Gowa, and Semarang, is an action that is not justified according to Islamic legal norms. For testing whether the product or the results of excavation of Islamic law are in harmony with the benefit that is the goal of the Islamic religion, then maqasid syaria is presented. Specifically, among the various types of maqashid syaira, the type of hifdzu al 
karamah al insaniyyah (maintaining human glory) according to Abdul Majid Najjar which is a branch of the general concept of hifdzu an-nafs (protecting life) is very relevant as the initial foothold, the direction law, as well as legal control.

The corpse infected by Covid 19 which was declared as "syahid akhira", or even if there were no such claims, received a respectable view of Islam. That is because the glory of man has been carried since he was created, without any frills, and remained until he died. The final form of respect for the glory or honor that human beings - in this case - is the body of Covid 19, is to take care and to handle according to Islamic legal norms. Therefore, based on the basic principles of maqashid hifdzu al karamah al insaniyyah, the "unjustified" claim of the rejection of the corpse infected by Covid 19 was extracted from 3 authoritative opinions of ulama ', as well as 2 types of fiqh rules above, considered as a product of Islamic law that had been in harmony with maqashid syaria.

\section{Conclusion}

After discussing and analyzing the rejection corpses infected by Covid 19 above, some conclusions that can be written are: In line with the conclusions above, the authors submit suggestions to the central and local government to be more massive in carrying out a process of educating the grass root community about the anticipation and handling of the Covid 19 pandemic wisely. For people, it is not easy to believe in broadcasts whatsapp or news that cannot be ascertained the truth, and to address this problem by promoting collective awareness and social solidarity. For academicians, to enliven the response and scientific opinion of the Covid 19 pandemic based on scientific research and observations aimed at helping the government in maintaining the physical and spiritual health of the community. 


\section{Bibliography}

Ad-Dimyathi, A. B. (t th). Hasyiyah I'anah At-Thalibin. Ihya' Al-Kutub Al-Arabiya.

Al-Anshari, Z. (2010). Tuhfat At-Thullab. Surabaya: Maktabah Al-Hidayah.

Al-Bantani, M. U. N. (2008). Nihayatuzzain fi Irsyad Al-Mubtadiin. Al-Kutub AlIlmiyyah.

Al-Ghazali, A. H. (1983). Al-Mustashfa fi 'Ilmi al-Ushul. Beirut, Al-Kutub Al-Ilmiyyah.

An-Naisaburi, M. (2008). Sahih Muslim. Jam'iyyah Markaz Al-Islamiy.

An-Nawawi, Y. (t.t) Al-Majmu' Syarh Al-Muhazzab. Al-Kutub Al-Ilmiyyah.

As-Suyuthi, A. R. (1982). Al-Asybah Wa An-Nadzair. Beirut. Darul Kutub AlIlmiyyah.

As-Syatibi, A. I. (1997). Al-Muwafaqat. Lebanon: Dar-Al-Ma'rifah.

Cohen, S. (2002). Folk Devils and Moral Panics. London: Routledge.

Baroroh, U. E., \& Janah, T. N. (2016). Fiqh Sosial: Masa Depan Fiqh Indonesia. Pati: IPMAFA Press.

Mahfudh, S. (2010). Al-Bayan Al-Mulamma' 'An Alfadz Al-Luma', Pati: Mabadi Sejahtera.

Mahfudh, S. (2007). Nuansa Fiqh Sosial. Yogyakarta: LKiS.

Najjar, A. M. (t.t). Maqashid As-Syariah Bi Ab'adin Jadidah.

Noortyani, R. (2013). Kepanikan Moral dalam Novel Lelaki Harimau Karya Eka Kurniawan. Banjarmasin: Proceedings The 23 HISKI Conference and Literature.

Zhou, Wang. (2020). The Coronavirus Prefention Handbook, (Ebook).

Zed, M. (2003). Metode Penelitian Kepustakaan. Jakarta: Yayasan Obor Indonesia.

Zuhaili, W. (2015). Al-Wajiz fi Ushul Al-Fiqh. Rembang: Al-Maktabah Al Anwariyyah.

htthps://www.liputan6.com/health/read/4225133/ahli-forensik-jika-inangmeninggal-virus-corona-covid-19-pun-mati\#

hthps://www.cnbc.com/2020/03/11/watch-live-who-holds-press-conference-onthe-coronavirus-outbreak.html

htthps://www.worldometers.info/coronavirus/

htthps://regional.kompas.com/read/2020/04/12/07351191/3-terdugaprovokator-penolakan-pemakaman-jenazah-perawat-positif-covid19?page $=2$

htthps://regional.kompas.com/read/2020/04/05/06170031/ini-sederet-alasanwarga-di-berbagai-daerah-tolak-pemakaman-jenazah-korban?page=3 
htthps://regional.kompas.com/read/2020/04/03/06070011/duduk-perkarapenolakan-pemakaman-pasien-covid-19-di-banyumas-bupatiminta?page $=3$

htthps://regional.kompas.com/read/2020/04/01/18000091/ditolak-warga-2kali-hingga-gali-liang-lahat-8-meter-fakta-penolakan-jenazah?page=1

htthps://www.liputan6.com/regional/read/4218139/polisi-amankan-5provokator-aksi-demo-penolakan-pemakaman-jenazah-pdp-di-gowa

htthps://www.cnnindonesia.com/nasional/20200426125652-12-497379/tigatersangka-penolak-jenazah-corona-semarang-siap-disidang

htthps://jateng.suara.com/read/2020/04/10/190258/klarifikasi-penolakjenazah-perawat-terinfeksi-corona-saya-menangis,

htthps://www.the-scientist.com/news-opinion/biochemist-stanley-cohen-dies$\underline{67080}$ 